\title{
ADAPTABILITY OF SECURITIZATION MODEL TO CONDITIONS OF VOLATILE FINANCIAL STRUCTURE
}

\author{
Dragana Bašić1, Predrag Ćurić ${ }^{2}$
}

date of paper receipt:

17.04.2021.

Original Article date of sending to review:

19.04.2021.

doi: 10.2478/eoik-2021-0012 date of review receipt:

10.05.2021.

UDK 339.747:336.781.5]:005.334

${ }^{1}$ University of Banja Luka, Faculty of Economics, Banja Luka, Republic of Srpska, Bosnia and Herzegovina, e-mail: dragana.basic@ef.unibl.org

${ }^{2}$ NLB Bank a.d. Banja Luka, Republic of Srpska, Bosnia and Herzegovina, e-mail: predrag.curic@yahoo.com

\section{ABSTRACT}

The Great Financial Crisis of 2008 exposed certain weaknesses in the field of investment banking and the necessity to adapt certain innovative solutions to the newly created economic and financial environment. The process of securitization is a financial innovation, which some financial analysts consider one of the causes of the Great Financial Crisis. Although it is often linked to the emergence of the Great Financial Crisis, the advantages of the securitization model, together with a level of adaptability and enhanced process control throughout all procedural levels, significantly outweigh its perceived shortcomings.

The financial system of the Republic of Srpska continues to be characterized by the growth of nonperforming loans in bank assets, mainly caused by increased systemic risk due to the current COVID-19 pandemic and declining economic activity in the country, but also by a well-developed financial system infrastructure, which is necessary in order to allow the application of the securitization model to significantly contribute to increasing financial stability in the conditions of volatile financial structure. The model of securitization of nonperforming loans and its application in the process of bank restructuring can be the mainstay of the stabilization of the financial system. The aim of the research is to demonstrate that the application of the adapted securitization model of nonperforming assets of banks and its application in the process of bank restructuring in the conditions of unstable financial structure may contribute to financial stability and control of increase of a systemic risk.

Securitization increases the supply of quality financial instruments, the number of participants in the process of transformation of financial assets and develops a more resilient financial market. The results include emergence of additional funding sources for financial institutions, generation of nonperforming assets' problems, with additional liquidity and diversification for many of their clients.

\section{Keywords:}

Securitization, Standardization, Credit Improvement, Systemic Risk, Non-Performing Loans, Bank Restructuring, Financial Stability 


\section{INTRODUCTION}

The economic, scientific and professional community generally believes that the onset of the global financial crisis in 2008, which later evolved into a broader and more comprehensive economic crisis, was caused by a very intensive spread of financial innovations and the process of intensive deregulation in the area of finance that preceded the crisis. Financial markets across the world have experienced very dynamic and major changes in recent decades, accompanied by the emergence of an enormous number of financial innovations, which contributed to their expansion as well as to the growth of the volume and type of business activities in such markets.

Delivorias states that the crucial contribution of the securitization process to the Great Financial Crisis was through the extension of the chain of intermediation, mismatch of motives and interests of participants involved in the securitization chain, lack of due diligence, together with an increased, excessive reliance on mathematical models and external risk assessments and, ultimately, through increased intensity of individual and systemic risks of banks (Delivorias, 2016, p. 15).

The extension of the intermediation chain through the inclusion of numerous new participants in the securitization process has made the system more complex while making the financial system less stable, whereby the inconsistent motives in the securitization chain have weakened the due diligence principle of the participants in the process. Complex structures such as synthetic securitization or re-securitization allowed speculation and failed to contribute to the real economy. Excessive reliance on mathematical models and external risk assessments without reliable data, i.e. without accurate input components, failed to result in positive effects in quality risk assessment.

A number of investors relied on external portfolio risk assessments provided by credit rating agencies, which were paid directly by originators to assess and steer their financial products. The abandonment of the traditional model of assessing the credit rating of issuers, real estate value and real estate market risk, i.e. the value of mortgages, which was traditionally in the domain of banks, and the appointment of specialized rating agencies has significantly contributed to the escalation of the Great Financial Crisis to the extent known today.

The possible, greatly significant initial impetuses of the Great Financial Crisis on the securitization side were also present with the original assets of the originators in the securitization process when it comes to method of financing mortgage placements of banks from their clients' deposits due to increasing demand for loans and lack of liquid assets. Another significant impetus of the Great Financial Crisis in the mortgage financing process was the potential risk of orderly servicing mortgage-backed securities (MBS) issued on the basis of mortgage assets of the banks in the pool, on the account of the prospective absence or irregularity of cash flows from original pool assets which is often a result of insufficient activity level of the originator banks on verifying the mortgages they release. (Bašić \& Plakalović, 2019, p. 281)

Although the securitization process has received significant criticism from the professional and scientific community on the account of its contribution to the growth and escalation of systemic risk, its application, together with adaptation to altered market conditions can greatly contribute to overcoming risk, increasing liquidity and profitability.

The aim of the research is to consider all the observed shortcomings of the asset securitization model, to evaluate the advantages of the model application, and to generate a securitization model according to the altered features of the market and economic environment and the conditions of volatile financial structure.

The paper is based on the general hypothesis that an adapted securitization model in the conditions 
of an altered market environment and volatile financial structure may contribute to reduced risk, increased liquidity and profitability of participants in the process of financial asset transformation. The focus of the research is the problematic issue of whether the participants in the financial system of the Republic of Srpska are able to generate positive effects of an adapted securitization model in order to increase liquidity and maintain the financial stability of the system.

In its fundamental, initial form, asset securitization is the process of grouping homogeneous loans and the sale of such assets to special purpose entities (or to trusts, trade unions). Then, marketable securities are issued against the grouped assets performed by the entity that organized the "pull" of those loans. Payment of interest and principal on issued securities directly depends on the cash flows arising from the fundamental "collected" and grouped assets on the basis of which the securities were issued. (Bašić \& Plakalović, 2019, p. 36)

"Asset securitization is a financing tool that can be used to mobilize financial resources for innovative activities, as well as for investment facilities. Issuing securitized assets means emission of securities guaranteed by money flows from the objects of securitized assets" (Vasilevna Nikolova et al., 2016).

"Securitization is a financing technique by which homogeneous income-generating assets (which on their own may be difficult to trade) are pooled and sold to a specially created third party, which uses them as collateral to issue securities and sell them in financial markets." (Delivorias 2016, p. 6).

It is important to point out several key aspects of the securitization process that make it significant and efficient in the process of transformation of financial assets, namely collateral, credit improvement, i.e. enhancement, standardization and liquidity. (Bašić \& Plakalović, 2019, p. 145)

Collateral represents transaction support, whereas the cash flow and credit characteristics of a collateral determine the performance of securities structured in the securitization process. Through its wide internal and external range, credit enhancement represents the process by which securities can be protected from losses or other risks associated with the original collateral. In general, standardization represents the process of harmonizing the methodology for approving different types of loans with maturities and other conditions within certain standard, common frameworks. Compliance documentation and signing are important aspects of standardization. Standardization facilitates the investor's understanding of collateral, cash flows, and basic loan risk in the pool. If there is a very broad differentiation in the structure and forms of loans offered, the investors need to analyze each loan individually, which requires additional costs and by no means satisfies the principle of cost-effectiveness. Liquidity determines the marketability of issued securities transferred to investors.

The located problems and limitations in the application of the securitization model have not significantly reduced confidence in this financial mechanism, which has been confirmed by the recently reached interim agreement between the Council of Europe, the European Parliament and the European Commission on changes in the European securitization market. (Arthurcox, 2017) Namely, in 2015, the European Commission launched an initiative to form the Capital Markets Union with the objective of reviving European securitization to pre-crisis levels. The new regulatory framework continues to apply securitization in the European administrative area as traditional and synthetic with its traditional characteristics and with key, traditional financial products of European securitization such as asset-backed securities (ABS) and collateralised debt bonds (CDO).

In the concluded interim agreement, that is, in the regulation, the European Commission stressed the importance of securitization as a tool for financing and risk transfer with the intention of "revitalizing" a simple, transparent and standardized securitization (STS securitization) model in 
order to free the capacity of banking balance sheet structures and use investment opportunities on a long term.

The securitization process will also find its place in the future in the green bond market, i.e. in investments that bring social and environmental benefits. "A securitization can be defined as 'green' when the underlying cash flows relate to low-carbon assets or where the proceeds from the deal are earmarked to invest in low-carbon assets such as mortgages on certified buildings, loans or leases on electric vehicles, on solar and wind assets or equipment (e.g. EV charging stations), loans for energy efficiency improvements and loans to climate-aligned SMEs." (Climate Bonds Initiative, 2018)

According to the IFC and the Climate Bonds Initiative, since June 2018, the largest issuer of green bonds in this emerging market has been China with an issue value of 57.1 billion dollars, followed by Mexico with 6.7 billion dollars and India with 6.6 billion dollars. (Bašić \& Plakalović, 2019, p. 289)

The application of the securitization model in the management of non-performing loans (NPL) can have positive effects in banking and significantly affect the reduction of their non-performance, increase of liquidity and stabilization of the banks' profitability. Securities emitted in the process of securitization of non-performing loans are usually assessed as bad bonds, but with a high yield due to low-quality, high-risk collateral as cover.

Securitization of non-performing loans was addressed by John Fell, Claudia Moldovan and Edward O'Brien. (Fell et al., 2017) The authors award great importance to the NPL securitization mechanism in resolving non-performing loans, together with emphasizing the need to improve certain support tools such as guarantees for junior NPL securitization tranches, including the purchase of direct tranches and defining future purchase scheme. They mention the importance of better harmonization of public and private sector interests, in order to increase the interest of current investors in NPLs by means of defined support tools and creation of asset classes that are attractive to a wider range of investors. According to them, the role of the state is crucial through the readiness to take certain measures in solving NPL problems in order to minimize investment risks and strengthen market confidence, which again depends on the efficiency of implementing defined tools for NPL valuation and sale.

The first significant step in the application of the securitization model for the sake of resolution of NPL problem in Europe was made by the Government of Italy in February 2016 by adopting certain legal solutions related to allowing state guarantees for the securitization of NPLs. (Deloitte, 2016) This was the effort to use the securitization model as a form of financing in resolving the issue of NPLs and create a new financial product, attractive to potential investors. Significant support to the unabated functioning of NPL securitization are credit service platforms for management and servicing of underlying assets, whose intensive activation in financial markets has opened a new market for mergers and acquisitions of existing service credit platforms between banks and funds. In her work, the author Nemlioglu also mentioned the possibility of securitization of intellectual property rights, i.e. the possibility of creating financial instruments from intellectual property such as patents or trademarks, and sees it as a method for extracting added value from intellectual property rights. (Nemlioglu, 2019)

In their work, Warner and Boas even emphasize the advantages and disadvantages of a possible institutional attempt to securitize climate change (Warner \& Boas, 2019).

Financial institutions shall encounter new competitors in the upcoming future, together with 
radical changes in the demographic structure, growing expectations of service users and changes in regulation, particularly towards the information technology. These trends will significantly affect the new strategic commitments and directions of modern financial institutions. The focus will be on innovative solutions and innovative technologies adapted to the requirements of the given environment that significantly facilitate banking, such as comprehensive and inclusive banking executed through new types of banking models, non-traditional alliances, as well as Fintech opportunities for bank clients in which adaptive securitization process in the increasing risk conditions and volatile financial structure certainly occupies its own significant place.

\section{RESEARCH METHODS}

During the research, a combination of quantitative and qualitative research methods was used in the paper, depending on the specificity and complexity of the subject to be researched. The application of the general scientific method was inevitable throughout the course of the research in order to discover and recognize the general laws and cause-and-effect relationships together with their comparisons with the specifics that characterize the area being researched.

Quantitative research methods have been used to gather adequate numerical data, with the aim of elaborating and investigating the relationship between variables and establishing cause-andeffect relationships among the phenomena observed. Considering the peculiarities of the research subject, the use of the historical method, mathematical-statistical methods and descriptive method in combination with comparative-quantitative methods was necessary. They were used to elaborate the meaning of the observed phenomenon, confirm the initial hypothesis and verify the research conclusions. With the aim of performing a deeper research, there was a need for a broader analysis of some global units or the need to generalize the analyzed individual segments which resulted in the application of the deductive and inductive methods. For a more comprehensive analysis of the assessed problem and a more thorough assertion of the set hypotheses, we used the survey as a research method, table research and field research. The survey was conducted on a sample of 8 banks based on a structured questionnaire with a number of questions related to the degree of innovation in banks, the level of knowledge and expertise of staff, as well as infrastructure capacity of banks to effectively participate in the securitization model as an innovative process.

During the research, in addition to primary sources, a number of secondary research sources was also used, such as various financial and publicly available publications, periodic bank reports, reports of entity Banking agencies, as well as published scientific and professional papers of eminent experts in the respective field.

\section{RESEARCH RESULTS}

The results of the empirical research showed that the total financial assets of banks in the Republic of Srpska in the period 2018-2020, which may be subject to securitization tend to increase. However, the cover rate and the quality of collateral are on a significant decline. Due to the significant derecognition of nonperforming loans, the cover rate by value adjustments, i.e. the rate of ECL on total financial assets amounts fo $4.0 \%$ and is lower by 0.4 percentage points compared to the end of the year 2019.

The cover rate of loans to legal entities and individuals in 2020 amounted to $6.51 \%$ and was lower by 0.39 percentage points in comparison to the year 2019. In 2020, the cover rate of loans to legal entities and individuals according to the credit risk levels was as follows: 
- For the credit risk level 1 in the amount of 4.6 billion BAM, i.e. $84.7 \%$ of the total credit exposure of $1.4 \%$;

- For the credit risk level 2 in the amount of 547 million BAM, i.e. 9.9\% of the total credit exposure of $11.3 \%$;

- For the credit risk level 3 in the amount of 287 million BAM, i.e. 5.2\% of the total credit exposure $80.8 \%$.

Table 1. Total financial assets according to credit risk levels

\begin{tabular}{|c|c|c|c|c|c|c|c|c|c|}
\hline \multicolumn{7}{|c|}{ Total financial assets according to credit risk levels } & \multicolumn{3}{|r|}{$\begin{array}{c}\text { Million } \\
\text { (BAM) }\end{array}$} \\
\hline \multirow[b]{2}{*}{ FINANCIAL ASSETS } & \multicolumn{3}{|c|}{2018} & \multicolumn{3}{|c|}{2019} & \multicolumn{3}{|c|}{2020} \\
\hline & Amount & ECL & $\begin{array}{l}\text { Cover } \\
\text { rate }\end{array}$ & Amount & ECL & $\begin{array}{l}\text { Cover } \\
\text { rate }\end{array}$ & Amount & ECL & Cover rate \\
\hline TOTAL & $8,935.3$ & 465.6 & 5.2 & $9,502.3$ & 422.8 & 4.4 & $9,773.3$ & 391.8 & 4.0 \\
\hline Credit risk level 1 & $7,758.5$ & 47.5 & 0.6 & $8,559.0$ & 53.4 & 0.6 & $8,835.5$ & 73.1 & 0.8 \\
\hline Credit risk level 2 & 628.8 & 38.9 & 6.2 & 525.2 & 47.3 & 9.0 & 630.0 & 68.0 & 10.8 \\
\hline Credit risk level 3 & 548.0 & 379.2 & 69.2 & 418.0 & 322.2 & 77.1 & 307.8 & 250.8 & 81.5 \\
\hline Balance & $7,988.5$ & 457.9 & 5.7 & $8,438.5$ & 414.5 & 4.9 & $8,644.0$ & 380.6 & 4.4 \\
\hline Credit risk level 1 & $6,906.8$ & 43.7 & 0.6 & $7,562.7$ & 49.3 & 0.7 & $7,766.8$ & 66.3 & 0.9 \\
\hline Credit risk level 2 & 540.9 & 36.9 & 6.8 & 459.6 & 43.6 & 9.5 & 570.4 & 64.0 & 11.2 \\
\hline Credit risk level 3 & 540.8 & 377.4 & 69.8 & 416.2 & 321.7 & 77.3 & 306.7 & 250.3 & 81.6 \\
\hline Off Balance & 946.8 & 7.6 & 0.8 & $1,063.8$ & 8.3 & 0.8 & $1,129.3$ & 11.2 & 1.0 \\
\hline Credit risk level 1 & 851.7 & 3.9 & 0.5 & 996.3 & 4.1 & 0.4 & $1,068.7$ & 6.8 & 0.6 \\
\hline Credit risk level 2 & 87.9 & 2.0 & 2.2 & 65.6 & 3.7 & 5.7 & 59.5 & 4.0 & 6.7 \\
\hline Credit risk level 3 & 7.2 & 1.8 & 25.3 & 1.8 & 0.5 & 26.9 & 1.0 & 0.5 & 46.9 \\
\hline
\end{tabular}

Source: Banking Agency of the Republic of Srpska, 2021.

The analysis of the credit indebtedness of sectors in 2020 in the Republic of Srpska showed that the largest credit burden is on the population sector amounting to 2.5 billion BAM (total consumption 1.67 billion BAM, housing construction 720 million BAM and activity performance 184 million BAM), followed by the public administration, defense and compulsory social insurance with 620 million BAM, wholesale and retail sector with 593 million BAM, processing industry with 506 million BAM, civil industry 237 million BAM and production and supply of electricity, gas and steam with 159 million BAM. (Banking Agency of the Republic of Srpska, 2021)

In 2020, the highest rates of nonperforming loans were in the education sector $16.4 \%$, wholesale and retail trade $11.1 \%$, agriculture, forestry and fishing $11.2 \%$ and manufacturing industry $10.3 \%$. The analysis of the volume of approved loans by individual categories showed a significant increase in credit indebtedness of the population sector compared to 2019 by $2.8 \%$. Loans were approved with a cover rate of $6.4 \%$, a share of nonperforming loans of $5 \%$ and a cover rate of $85.3 \%$. The share of loans for housing construction covered by mortgages tended to increase one year after another, and according to analyzes for the year 2020, the cover rate is $3.1 \%$ with an NPL rate of $2.5 \%$ and an NPL cover rate of $82 \%$. The obtained characteristics of sectoral indebtedness provide sufficient volume and quality of the asset portfolio in the banks of the Republic of Srpska, which could serve as collateral for the issue of securities covered by mortgages, i.e. for development of MBS system in the banking, that is, financial system of the Republic of Srpska.

In Bosnia and Herzegovina, systemic risks are very much pronounced, which imposes the necessity for further affirmation of the risk management area in the investment policy of banks in Bosnia and Herzegovina. 
The use of modern financial innovations for risk transfer in the current conditions is limited due to the fact that modern financial innovations, which offer greater liquidity and the possibility of hedging transactions, are modestly used in the economic environment of Bosnia and Herzegovina. The development of financial innovations in Bosnia and Herzegovina presupposes a certain degree of development of the underlying securities market, both in terms of its depth and in its breadth. A more thorough and comprehensive analysis and research of the credit sector and financial innovation in order to prove the set hypothesis and define the assumptions of creating and implementing a securitization model in a volatile financial structure, by means of performing a survey among the banks resulted in the following.

According to the results of the analysis, all surveyed banks monitor financial innovations in modern financial markets and innovate their processes and products, but lack qualified departments for such purpose. As the main reasons that hinder the monitoring, creation and implementation of new financial products, they state that financial innovations have not been implemented in legal regulations and procedural form, the financial market is insufficiently developed and IFRS regulating this area are incomprehensible.

Seven surveyed banks were introduced to the concept and advantages of applying the loan securitization model as an innovative banking process, emphasizing the availability and readiness for its implementation once the required preconditions are met. As an argument for their positive attitude, the banks pointed out the relatively successful collection of credit placements and security of loans by means of a proper collateral. Only one of the surveyed banks responded that it was not familiar with the concept and benefits provided by securitization and other financial innovations, but that it was willing to cooperate on their implementation and include them in its product and service portfolio.

The surveyed banks mainly follow the development and implementation of financial innovations in modern financial markets. The entry of foreign financial institutions into the banking system and the adjustment to international standards and Basel principles have contributed to their development.

None of the banks or other financial entities in the Republic of Srpska has yet decided to develop a program for securitization of their assets, although the structure and quality of assets of the analyzed banking sector allows for such step, whereby the positive legal regulations neither prohibit nor exclude it.

In order for the securitization model to be successfully developed and effectively applied in the context of local conditions of volatile financial structure, it is necessary to establish adequate financial infrastructure in terms of providing economic and organizational preconditions (development of economic, legal, tax and accounting system), providing technological equipment and staffing of banks and other participants in the process, as well as in terms of more intensive development of the capital market in the country in all of its segments.

Empirical research has confirmed the existence of certain institutional preconditions for the creation and implementation of asset securitization models.

In Bosnia and Herzegovina, in both of its entities, the fundamental institutions have been established, such as capital markets, the Sarajevo and Banja Luka Stock Exchanges, the Securities Commission responsible for capital market regulation and investor protection, the Central Securities Depository, as well as a number of brokerage houses and brokerage departments within existing banks.

Both entities have adopted the Law on Banks, the Law on Companies and the Law on the Securities Market, all of which have been adapted in line with the European directives. Certain elements of 
the legal framework in Bosnia and Herzegovina are harmonized with identical regulations of both entities, such as the Law on Public Enterprises, the Law on Banks, and the Law on Insolvency. A necessary condition for the functioning of the securitization model of loans and other forms of financial instruments from the securitization process is the provision and upgrading of legal regulations in this area (mortgage loans, amendments on the Law on Securities, upgrading of regulations in the field of stock exchange and market conduct in mortgage loans operations, etc.) as well as the increase of the efficiency of the judiciary system. All laws in Bosnia and Herzegovina are in the process of harmonization with the minimum standards of the European Union Directives, particularly in the field of issuing securities, i.e. mortgage bonds. The laws in that are force, in terms of their content, may very successfully support the loan securitization process, although it would be preferable, once the process is implemented, to further regulate this area with a specific legal framework. A very important and crucial moment is the obligatory introduction of the pledge register in accordance with the Directives of the European Union.

The Republic of Srpska entity has already formed a dedicated banking institution in the form of a company, which is the Investment and Development Bank, which holds certain preconditions for a quality and functional taking over as a specific financial agency in terms of refinancing securitized loans of originator banks.

Empirical research has shown that the financial assets of the Republic of Srpska banks serve as a sufficient basis for the application of the securitization model. However, a successful implementation of the process requires further intensification of banks' activities based on mortgage, housing and other loans that are the basis of securitization, adjustment of credit policy and procedures for approving, documenting and recording credit placements according to securitization processes and active participation of banks in financial and ownership restructuring of economic entities through a significant financial support in the form of large bank loans. A more massive turnover of real estate based on credit placements and more intensive development of the primary and secondary capital market are also necessary. Particular emphasis should be placed on the primary and secondary bond markets.

Speaking of the staffing of banks and other participants in the process in the region, the research results showed that the education of the bank staff on innovative processes in banking is quite low, which implies that the knowledge about the fundamentals of the securitization model are on a comparable level. In practice, certain educational programs are necessary, not only for bank employees as bearers of fundamental activities in the initial phase of introducing the securitization model, but also for other participants in the financial market process.

When it comes to technological equipment, the research showed that all banks in the banking market of Bosnia and Herzegovina have an adequate register and electronic data processing, as well as developed electronic networks. The loan securitization process is extremely unfeasible without electronic monitoring of individual mortgages via electronic networks for registration, performance monitoring and mortgage trading, as well as without electronic support necessary for adequate servicing of securitized loans in terms of principal and interest collection and redirection of cash flows to end customers of secondary securities from the securitization process, i.e. to investors. The key result of the research is the conception of a securitization model adapted to the domestic conditions of a volatile financial structure (Figure 1) 


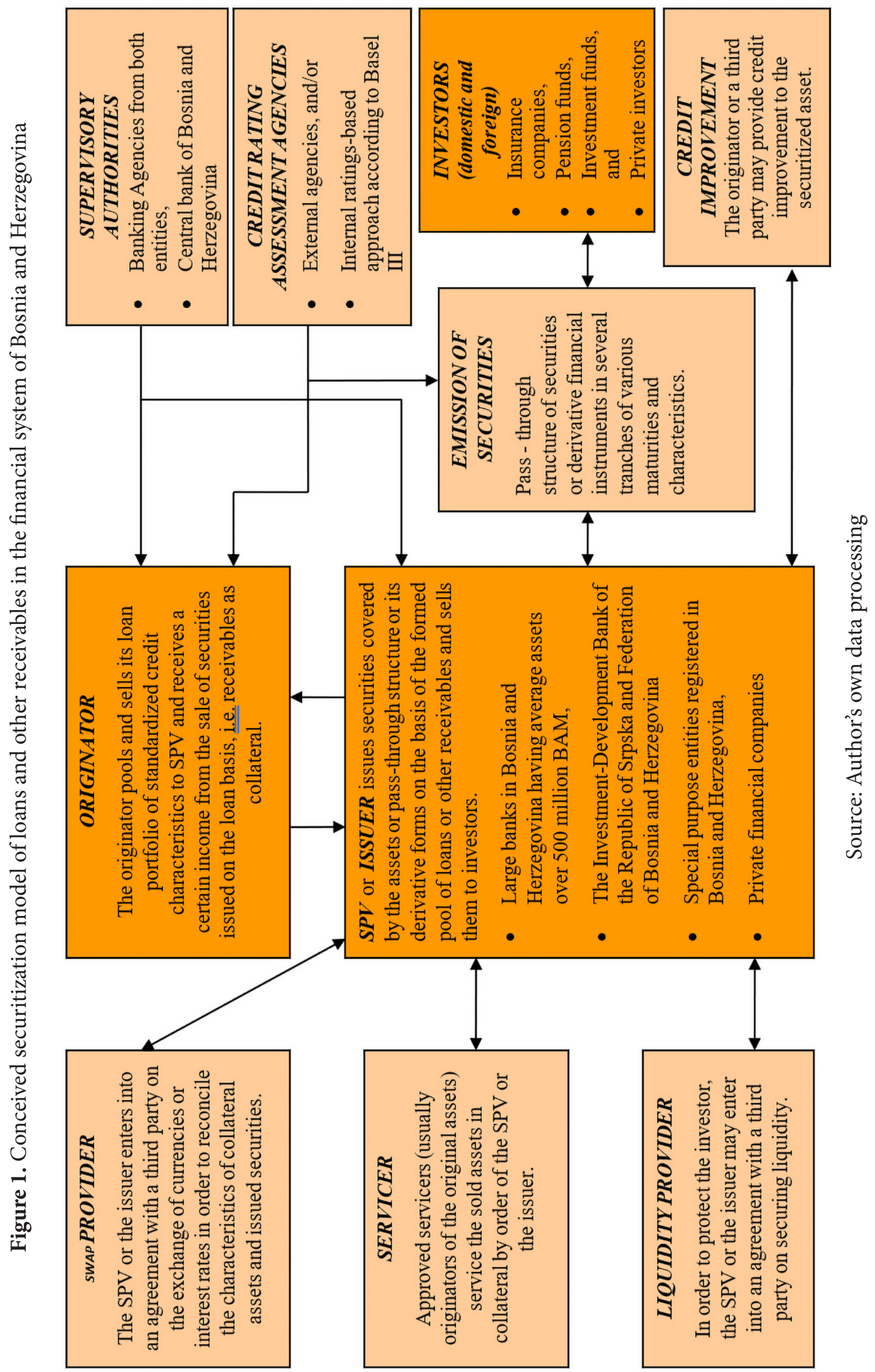


The conceptual model based on research of all necessaryinstitutional, economic, legal, organizational, technological and personnel preconditions envisages a loan model with MBS and ABS structure.

Based on the obtained research results, the subject of loan securitization can include all the categories of a loan portfolio (both good and bad) as well as the receivables, except those that are prohibited by applicable laws in terms of transfer and sale as assets (apart from mortgage loans, consumer loans banks, nonperforming loans of banks with bad credit ratings, debts of health, pension and social insurance funds, receivables from the process of bank restructuring and bankruptcy proceedings may be indluded as well).

According to the generated securitization model, the function of special purpose entities could be performed by: large banks with average assets of over 500 million BAM, Investment-Development Banks of the Republic of Srpska and Federation of Bosnia and Herzegovina and special purpose entities registered in Bosnia and Herzegovina.

In addition to special purpose entities and banks in Bosnia and Herzegovina, in the final, already developed phase of the securitization model and upon its successful implementation, the issuance of senior securities should be enabled to private financial companies, together with appropriate credit enhancements of assets, both internal and external. It is recommended that special purpose entities be subject to capital adequacy and minimum capital requirements, if the special purpose entity is a bank, in order to protect the interests of investors and other participants in the process of securitization of loans and other receivables. However, it is crucial that there is a public authority responsible for the prudential supervision of financial institutions in a securitization transaction, i.e. a body authorized to supervise loans and financial institutions. This competent authority needs to have a broad supervisory authority over loan securitization transactions and, according to the conceptual model, entity banking agencies or the Central Bank of Bosnia and Herzegovina are proposed.

Table 2. Financial indicators

\begin{tabular}{|c|c|c|}
\hline Category & Indicator & Value \\
\hline \multirow{2}{*}{ Profitability } & ROAA & 0.6 \\
\cline { 2 - 3 } & ROAE & 5.1 \\
\hline Credit risk & NPL & 5.2 \\
\hline \multirow{3}{*}{ Capital } & Common equity Tier 1 capital & 17.4 \\
\cline { 2 - 3 } & Tier 1 capital & 17.5 \\
\cline { 2 - 3 } & Regulatory capital & 19.3 \\
\cline { 2 - 3 } & financial leverage & 10.4 \\
\hline Liquidity & LCR & 200.3 \\
\hline
\end{tabular}

Source: Author's own data processing

The profitability ratios of the banking sector of the Republic of Srpska measured on the basis of the annual level of net profit and the average balance of assets and capital (13-month average) for 2020 show a decline. The ROAA coefficient is $0.6 \%$ and is lower by 0.6 percentage points, and the ROAE coefficient is $5.1 \%$ and is lower by 4.6 percentage points compared to the end of 2019 .

Credit and other placements have the largest share in the total structure of assets and are the most risky part of it. The loan portfolio accounts for $62 \%$ of gross balance sheet assets. Expected credit loss (ECL) is an adjustment to the value of balance sheet exposures and provisions to cover expected credit losses for off-balance sheet exposures that the bank records in the income statement. The total exposure of banks as at December 31, 2020 amounts to 9.8 billion BAM, of which 8.6 billion BAM 
refers to on-balance sheet exposures, and 1.1 billion BAM to off-balance sheet exposures. In 2020, balance sheet exposures increased by 205.5 million BAM or $2 \%$, while off-balance sheet exposures increased by 65.5 million BAM or 6\%. Due to the significant write-off of non-performing loans, the rate of coverage by value adjustments, ie the rate of ECL on total financial assets is $4 \%$ and is lower by 0.4 percentage points compared to the end of 2019 .

Loans allocated to credit risk level 3 (NPL) as at December 31, 2020 amount to 287.5 million BAM and account for $5.2 \%$ of the total loan portfolio. Compared to the end of 2019 , they are lower by 92.2 million BAM or $24 \%$, mostly due to the accounting write-off in accordance with the Decision on credit risk management and determining the expected credit losses of the Banking Agency of the Republic of Srpska.

Although these indicators support the application of the securitization process in the banking sector of the Republic of Srpska, no bank has used loan securitization, nor has an infrastructure platform been developed to support this process. Therefore, an analysis of the effects before and after securitization in the banking sector of theRepublic of Srpska is not possible.

Indicators of capital adequacy as at December 31, 2020 show that the banking sector of the Republic of Srpska is satisfactorily capitalized, taking into account the capital structure and indicators of capital adequacy that are above the prescribed minimums.

Regulatory capital is the sum of core and supplementary capital after regulatory adjustments and the bank is obliged to maintain it in the prescribed amount, for the purpose of safe and stable operations and fulfillment of obligations to creditors.

The regulatory capital rate is $19.3 \%$ and is higher by 1 percentage point compared to the end of 2019 (minimum prescribed rate of $12 \%$ ), the share capital rate is $17.5 \%$ and is higher by 0.7 percentage points (minimum prescribed rate of $9 \%$ ) and the rate of regular share capital is $17.4 \%$ and is higher by 0.6 percentage points compared to the end of 2019 (the minimum prescribed rate is $6.75 \%$ ), and all capital rates are significantly above the statutory minimum. Certain research has shown that banks that use securitization on average represent lower capital ratios than those that do not. (Cardone-Riportella, et al. 2010)

Leverage rates represent the ratio of share capital to the measure of the bank's total exposure on the last day of the reporting period, which must be at least $6 \%$. The leverage rate at the level of the banking sector of the Republic of Srpska is 4.4 percentage points higher than the minimum prescribed rate and amounts to $10.4 \%$.

In order to ensure the bank's short-term resilience to liquidity risk, banks are required to provide an appropriate level of liquidity buffer. The minimum liquidity coverage ratio (LCR), which represents the ratio between the level of the liquidity buffer layer and the total net liquidity outflows during the stress period of 30 calendar days, is prescribed in the amount of $\geq 100 \%$. All banks in the Republic of Srpska have LCR above the prescribed amount, and in this reporting period the total LCR at the level of the banking sector is $200.3 \%$. Certain research has shown that banks that deal with securitization on average have lower liquidity than those that do not. (Cardone-Riportella, et al. 2010)

\section{DISCUSSION}

The justification of the concept of securitization in the economies of transition countries such as Bosnia and Herzegovina stems from the underdevelopment of the financial market and the instability of the financial structure characterized by the issues of risk protection, liquidity and 
solvency of the real sector and provision of funding for financing growth and development.

Erićs allegations that bonds are basic assets for the development of fast-growing markets are also in favor of the application of the conceptual securitization model, as securities are considered as lowrisk by their fundamental function and that only they may be used to estalbish a sufficiently liquid market can be formed in a relatively unstable environment in the circumstances when the systemic risk is extremely high. (Erić, 2003, p. 313)

Given the significance of credit mechanisms in financing the real sector of the economy in the financial systems that are bank-centric, Kovaleva and associates classify securitization models according to the type of assets depending on the type of cash flow generated (securitization of existing receivables and securitization of future receivables) and depending on the mechanism of execution (classical and synthetic). (Kovaleva et al., 2018)

Vasilevna Nikolova and associates agree with The International Financial Corporation's approach to modeling the concept of securitization by distinguishing the models of traditional securitization via the "actual sales", synthetic securitization and whole business securitization. (Vasilevna Nikolova, 2016)

Depending on whether the initial assets in the form of mortgage loans remain in the banks' balance sheets or is excluded from their balance sheets and included in the balance sheets of specialized financial institutions, Živkov and Pavkov distinguish between the European (balance sheet securitization model) and American securitization model. (Živkov \& Pavkov, 2012)

The Great Financial Crisis in 2008, through its causes and consequences, provided a number of very important answers to the questions of the functioning and sustainability of the securitization model in the structure of modern financing models. The perceived problem of insufficient and inadequate control and regulation in this area motivated the creators of regulation in the field of banking and international financing to initiate the process of introducing a more stringent framework for securitization in order to make it more flexible and the securitization market sustainable and less risky. (Bašić \& Plakalović, 2019, p. 283) The conceptualized securitization model adapted to the volatile financial structure emphasizes the importance of the competent authorities for supervision and internal and external credit improvements.

The results of the research obtained by Kara and associates showed that in the pre-crisis period, banks mainly grouped and securitized corporate loans with very good credit performance, retaining corporate loans of lower credit quality in their assets. The research showed that the credit quality of borrowers whose loans were securitized after the securitization process significantly deteriorated compared to the control group, citing the weakening of bank monitoring activities following the securitization process. (Kara et al., 2017) The conceptualized securitization model adapted to the conditions of a volatile financial structure took into account the need to preserve the quality of the loan portfolio of originator banks involved in the process of transformation of financial assets through the securitization model. 


\section{CONCLUSION}

Bosnia and Herzegovina has taken several significant steps on its path of following modern European and worldwide financial flows by means of a unique path towards joining highly developed economic and financial regional groups. Despite significant changes in recent years, Bosnia and Herzegovina's financial system is still insufficiently dynamic and is underdeveloped.

The results of the research of the Republic of Srpska's banking sector showed the existence of a sufficient volume of financial assets in banks that could serve in the function of collateral for the issue of securities covered by mortgages, i.e. by the assets. Banks mainly monitor the development and implementation of financial innovations in modern financial markets, but in their practice lack more intensive activities in this area.

Capital adequacy indicators as at December 31, 2020 say that the banking sector of the Republic of Srpska is satisfactorily capitalized, taking into account the capital structure and capital adequacy indicators that are above the prescribed minimums. The financial leverage rate of the banking sector is 4.4 percentage points higher than the minimum prescribed rate. In addition, all banks in the Republic of Srpska have LCR above the prescribed amount, based on which we conclude that the overall liquidity rating of the banking sector of the Republic of Srpska is satisfactory. Based on these indicators, we can indicate to the readiness of the banking sector to be part of the model of securitization of nonperforming assets of banks, which is especially important in a situation where Bosnia and Herzegovina is rated as a country with non-investment risk, while the specific category of credit rating (Moody’s Investors Service - "B3" and Standard \& Poor's - "B"), describes as "speculative credit solvency, high credit risk".

Although securitization was designated as one of the causes of the Great Financial Crisis in 2008, confidence in this financial mechanism has not been significantly diminished, which has been confirmed by the recently reached interim agreement between the Council of Europe, the European Parliament and the European Commission on changes in the European securitization market. The significance of securitization as a tool for financing and risk transfer with the intention of "revitalizing" a simple, transparent and standardized (STS) securitization model in order to free the capacity of banking balance sheet structures and exploit the investment opportunities in the long run is still emphasized. Nowadays, in modern financial flows securitization has found its place in the issuance of green bonds, management of non-performing loans, management of health, social and pension insurance funds, management of intellectual property and climate change, and the like.

The application of the conceptual model of loan securitization in our conditions would provide a number of advantages for the economy and banking system of Bosnia and Herzegovina such as increasing liquidity of the financial system and strengthening institutional capacity, massification of financial instruments in the capital market, development of housing industry and investment funds, insurance companies, pension funds and other financial institutions in the financial markets, as well as a number of other benefits.

Implementing a loan "securitization" model would revive the non-functional funds in the financial system of Bosnia and Herzegovina, such as poor credit placements of banks and unpaid receivables of social and pension funds, strengthen the financial structure and boost overall economic activity, whereas Bosnia and Herzegovina would be introduced to the world of dominant financial trends in world practice.

The implementation of the model would represent a big step for the development of the financial 
system of Bosnia and Herzegovina, but also a significant capacity for its further research, improvement and adaptation given the changes in the environment and experiences during its implementation.

Securitization would further expedite the distancing of non-financial companies from traditional credit institutions through financial intermediaries and through self-financing and self-lending directly through open market investors. This process will inevitably encourage banks, insurance companies and other traditional intermediaries to become actively involved in the process of accelerated development of new services and processes in order to distance themselves from the potential harmful effects of new trends and increasing systemic risk on their future profitability.

In addition to the positive effects of applying the created model, certain possible limitations of implementation into our financial system are to be expected. Banks and other financial institutions that would plan the implementation of this model in their business strategy should make certain financial efforts in terms of technical - technological training and personnel support to the process. The implementation of the model requires nearly "impeccable" data files on loan placements, loan amortization and financial instruments from the securitization process, investors, issuers and other participants in the process.

The area of Bosnia and Herzegovina is traditionally characterized by "resistance to change", i.e. poor acceptance and adaptation to any innovations, not only financial ones, which is largely due to insufficient education of the population and legal entities on regional trends, but also due to the sluggishness of the system and lack of motivation. When observed from the regulatory aspect, the implementation of the model in Bosnia and Herzegovina requires efficiency, unity and homogenization of legal regulations, as well as compliance with European Union directives.

Ultimately, Bosnia and Herzegovina's financial system is still insufficiently dynamic and developed to be able to fully support the implementation of the securitization process, whereby the political system surrounding it is extremely complex, fragmented and unstable, making it unattractive to investors. 


\section{REFERENCES}

Arthurcox. (2017). Securitisation Reform: Agreement reached. Retrieved from http://www.arthurcox.com/wp-content/uploads/2017/06/Arthur_Cox_SecuritisationReform-Agreement-reached.pdf

Bašić, D., \& Plakalović, N. (2019). Mortgage financial market and securitization mechanisms. Banja Luka: Faculty of Economics, University of Banja Luka.

Climate Bonds Initiative. (2018). Bonds and Climate Change The State of The Market 2018. Retrieved from https://www.climatebonds.net/files/reports/cbi_sotm_2018_final_01h-web.pdf

Cardone-Riportella, C., Samaniego-Medina R., \& Trujillo-Ponce, A. (2010). What drives bank securitisation? The Spanish experience. Journal of Banking \& Finance, Vol. 34 (11), 26392651, doi: https://doi.org/10.1016/j.jbankfin.2010.05.003

Deloitee. (2016) Italian non-performing loan. State guarantee and securitisation scheme... Unlocking the NPL log-jam? Retrieved from https://www2.deloitte.com/content/dam/Deloitte/uk/Documents/corporate-finance/ deloitte-uk-fa-italian-nonperforming-loans.pdf

Delivorias, A. (2016). Understanding Securitization (Background - benefits - risks). European Parliamentary Research Service, 1-24, doi: 10.2861 / 788633

Erić, D. D. (2003). Finansijska tržišta i instrumenti (eng. Financial markets and instruments). II amended edition. Belgrade: Čigora Press.

Fell, J., Moldovan, C. \& O’Brien, E. (2017). Resolving non-performing loans: a role for securitisation and other financial structures? Financial Stability Review, 158-174. Retrieved from https://www.ecb.europa.eu/pub/pdf/fsr/art/ecb.fsrart201705_03.en.pdf?914a0eb2f9 b52060b52c82e12afa1a05

Kovaleva, T. M., Khvostenko, O. A., Glukhova, A. G., \& Mozharovsky, E. V. (2018). The Actual Problems of Assets Securitization in Commercial Organizations. Revista Espacios.,Vol. 39 (No22), 28-43, Retrieved from https://www.revistaespacios.com/a18v39n22/a18v39n22p28.pdf

Kara, A., Marques-Ibanez, D., \& Ongena, S. (2017). Securitization and credit quality. ECB Working Paper Series, 2009, 1-41, doi: 10.2866 / 696711

Nemlioglu, I. (2019). (2019). A novelty on unlocking businesses' potential growth: Intellectual PropertySecuritisation. Procedia Computer Science, 158, 999-1010, doi: 10.1016/2019.09.141

Vasilevna Nikolova, Lj., Grigorievich Rodionov, D., \& Bahauovna Mottaeva, A. (2016). Securitization of Bank Assets as a Source of Financing the Innovation Activity. International Journal of Economics and Financial Issues, 6(S2), 246-252. Retrieved from https://www.econjournals.com/index.php/ijefi/article/view/2559/pdf

Warner, J. \& Boas, I. (2019). Securitization of climate change: How invoking global dangers for instrumental ends can backfire, Environment and Planning C: Politics and Space, 37(8), 1472-1488, doi: 10.1177/2399654419834018

Živkov, D., \& Pavkov, I. (2012). Predimenzioniranje subprimarnog hipotekarnog tržišta kao glavni uzrok njegovog sloma. (eng. Oversizing the Subprimary Mortgage Market as the Main Cause of its Collapse.) School of Business, 3, 58-64, doi: 10.5937/skolbiz1203058Z 